\title{
Characterization of Diaporthe australafricana and Diaporthe spp. Associated with Stem Canker of Blueberry in Chile
}

Karina Elfar, René Torres, Gonzalo A. Díaz, and Bernardo A. Latorre, Facultad de Agronomía e Ingeniería Forestal, Pontificia Universidad Católica de Chile, Casilla 306-22, Santiago, Chile

\begin{abstract}
Elfar, K., Torres, R., Díaz, G. A., and Latorre, B. A. 2013. Characterization of Diaporthe australafricana and Diaporthe spp. associated with stem canker of blueberry in Chile. Plant Dis. 97:1042-1050.

Stem canker and dieback are important factors that limit the longevity and reduce the yield of blueberry (Vaccinium spp.) in Chile. In this study, species of Diaporthe associated with blueberry were isolated and identified. The internal transcribed spacer (ITS) regions of ribosomal DNA of 30 isolates and the translation elongation factor 1- $\alpha$ (EF1- $\alpha$ ) of 14 isolates were sequenced, analyzed, and compared with their morphological and pathological characteristics. The molecular analysis of ITS sequences by alignment with those of ex-type strains deposited in GenBank and morphological characteristics allowed the identification of Diaporthe ambigua, D. australafricana, D. neotheicola, D. passiflorae, and Diaporthe sp. 1. However, morphology alone was insufficient to identify these species. The combined analysis of ITS and EF1- $\alpha$ gene sequences grouped the Chilean blueberry

genicity tests conducted with attached and detached blueberry shoots ( $<1$ year old) and stems ( 1 to 2 years old) confirmed that isolates of these Diaporthe spp. were pathogenic. The symptoms were reproducible and consisted of necrotic reddish-brown cankers on blueberry shoots and stems. These isolates were capable of infecting blueberry fruit, causing a soft decay, suggesting that they were tissue nonspecific and were also pathogenic on shoots of apple, grapevine, and pear. $D$. australafricana was the most frequently isolated species and $D$. ambigua, D. australafricana, and D. passiflorae were highly virulent in shoots, stems, and fruit of blueberry. This study showed that at least four species of Diaporthe are primary pathogens, capable of causing stem canker symptoms on blueberry, and this is the first report of $D$. ambigua, D. neotheicola, and D. passiflorae attacking this host.
\end{abstract} isolates in the same five groups obtained in the ITS analysis. Patho-
Blueberry plants (Vaccinium spp.) are native to the eastern and northeastern United States, and were introduced into Chile in the early 1980s. Currently, blueberry is a high-value crop in Chile on more than 10,700 ha spread across $1,400 \mathrm{~km}$ from north to south, with a wide range of soil types and climates. Stem canker and dieback in blueberry plants are important factors limiting both their longevity and fruit production (6).

Several fungi are associated with stem canker and dieback in blueberry throughout the world, including species of Botryosphaeria $(17,36)$ Calonectria (18), Godronia (27), Lasiodiplodia (36), Neofusicoccum $(6,36)$, Pestalotiopsis $(7,11)$, and Truncatella (7). Additionally, Diaporthe (Phomopsis) vaccinii and other Phomopsis spp. have been described as causes of dieback and fruit rot in Vaccinium corymbosum and V. macrocarpon (cranberry) plants in North America $(8,9)$.

In view of the new criteria of one name for one fungus species (13), the older name Diaporthe Nitschke (1870) was preferred over its anamorph Phomopsis (Sacc.) Bubák (1905) in this study.

The genus Diaporthe has a wide geographical distribution in the world, with over 800 species (www.indexfungorum.org) that occur as endophytes, saprotrophs, and parasites in a very diverse range of host plants, including woody and herbaceous hosts (32). Pathogenic Diaporthe (Phomopsis) spp. can cause considerable economic loses in different crops and they are often associated with shoot blights, leaf spots, fruit rots, stem cankers, and dieback (32).

\section{Corresponding author: B. A. Latorre, E-mail: blatorre@uc.cl}

\footnotetext{
* The $\boldsymbol{e}$-Xtra logo stands for "electronic extra" and indicates that four supplementary figures are available online.
}

Accepted for publication 3 February 2013.

http://dx.doi.org/10.1094/PDIS-11-12-1030-RE

(C) 2013 The American Phytopathological Society
The identification of Diaporthe spp. has been based on morphology, cultural characteristics, and host specificity. However, this concept is no longer acceptable because of the difficulties associated with the variability of the morphometrical measurements among Diaporthe spp. and considering that several species of $\mathrm{Di}$ aporthe have a wide host range and more than one species can be associated with the same plant host $(21,31)$.

Molecular analysis and phylogeny has been developed as important complementary tools for fungal identification (26). The analysis of the internal transcribed spaces (ITS) of the nuclear ribosomal DNA (rDNA) is the most widely used analysis for the identification of species of Diaporthe and other fungal species $(23,24,33,34)$. However, multilocus phylogeny combining sequences of ITS of rDNA, translation elongation factor 1- $\alpha(\mathrm{EF} 1-\alpha), \beta$ tubulin, and calmodulin genes has been proposed as a useful tool to delimit species boundaries within the genus Diaporthe $(31,32)$. Additionally, the mating type genes (MAT) have been also used (22).

In recent studies conducted in Chile, several isolates of the $D i$ aporthe (Phomopsis) complex were reported to be associated with stem canker $(15,16)$, alone or coexisting with species of Neofusicoccum (6). Recognizing that identification is important for developing effective control strategies, the objective of this study was to further identify and characterize the species of Diaporthe associated with Vaccinium spp. in Chile.

\section{Materials and Methods}

Sampling locations and fungal isolation. Symptomatic 1- to 2year-old stems were collected from 14 commercial plantings of northern high-bush blueberry (V. corymbosum) and southern highbush blueberry ( $V$. corymbosum $\times V$. darrowi) between Ovalle $\left(30^{\circ}\right.$ $36^{\prime}$ latitude $\mathrm{S}$ ) and Osorno (40 53' latitude S) (Table 1). Samples were surface sterilized in $96 \%$ ethanol for $15 \mathrm{~s}$. Small fragments of necrotic tissue were cut from the margins of the necrotic lesions and placed on potato dextrose agar (PDA) acidified with $92 \%$ lactic acid at $0.5 \mathrm{ml} \mathrm{liter}^{-1}$ and containing $0.005 \%$ tetracycline, $0.01 \%$ streptomycin, and 0.1\% Igepal CO-630 (APDA; Sigma-Aldrich). The cultures were incubated in the dark at $20^{\circ} \mathrm{C}$ until colonies were 
observed. Pure cultures were obtained from samples taken from the hyphal tips at the margin of the suspected Diaporthe colonies and subcultured on fresh APDA at $20^{\circ} \mathrm{C}$.

Morphological identification. Fungal colonies were first identified based on colony and conidial morphology. To enhance pycnidia and perithecia formation, 4-day-old mycelial plugs of 28 isolates were cultivated on autoclaved alfalfa (Medicago sativa L.) and blueberry stems placed on $2 \%$ water agar (8), then incubated for 14 days at room temperature $\left(20\right.$ to $\left.22^{\circ} \mathrm{C}\right)$ prior to incubation at 5,10 , or $20^{\circ} \mathrm{C}$ for 60 to 90 days in darkness. The presence or absence of pycnidia and/or perithecia was then determined. Only sporulating pycnidia and perithecia were recorded as fertile. The size of $\alpha$-conidia $(n=20), \beta$-conidia $(n=20)$, and ascospores $(n=$ 20) was measured and compared with published descriptions (32).

Molecular characterization. DNA was isolated from the mycelia of pure isolate cultures grown for 14 days on APDA using a commercial DNA extraction kit (Axygen Biosciences). The ITS15.8S-ITS2 region of the nuclear rDNA of 30 Diaporthe isolates was amplified using primers ITS4 and ITS5 (35) and the translation elongation factor $1-\alpha(E F 1-\alpha)$ of 14 Diaporthe isolates was amplified using primers EF1-728F and EF1-986R (3). The DNA was stored at $-20^{\circ} \mathrm{C}$. Polymerase chain reactions (PCR) were conducted in a thermal cycler (Axygen Biosciences). Each PCR reaction sample contained $2.5 \mu \mathrm{l}$ of $10 \times$ PCR buffer, $1.0 \mu \mathrm{l}$ of 25 $\mathrm{mM} \mathrm{MgCl} 2,0.5 \mu \mathrm{l}$ of $10 \mathrm{mM}$ dNTPs, $0.5 \mu \mathrm{l}$ of a $0.5-\mathrm{mM}$ solution of each primer, $0.2 \mu \mathrm{l}$ of Taq DNA polymerase (Invitrogen) at 5 units $\mu \mathrm{l}^{-1}$, and $1 \mu \mathrm{l}$ of template DNA in a final volume of $25 \mu \mathrm{l}$. A negative control was always included. The thermal cycle protocol was preheating for $2 \mathrm{~min}$ at $94^{\circ} \mathrm{C}$; followed by 35 cycles of denaturation at $94^{\circ} \mathrm{C}$ for $60 \mathrm{~s}$, annealing at $58^{\circ} \mathrm{C}$ for $60 \mathrm{~s}$, and extension at $72^{\circ} \mathrm{C}$ for $90 \mathrm{~s}$; with a final extension for $5 \mathrm{~min}$ at $72^{\circ} \mathrm{C}$. The PCR products were separated on $2 \%$ agarose gels in $1.0 \times$ Tris-acetate-EDTA buffer, stained with GelRed (Biotium Inc.), and visualized by UV transillumination at $320 \mathrm{~nm}$.

The PCR-amplified products were purified and sequenced from both directions by Macrogen Inc., South Korea. A BLAST search was done against sequences (Table 2) in the GenBank (www. ncbi.nlm.nih.gov) database.

The sequences were edited using Proseq v.2.91 (10) and aligned using ClustalX v.2.1 (14) with ITS sequences from representative Diaporthe/Phomopsis spp. deposited in GenBank (Table 2). Considering that known sequences of EF1- $\alpha$ for all the taxa were not available in GenBank, only a tree with the ITS sequences was obtained. However, a concatenated tree was obtained. Prior to this, the congruence of the evolution between the ITS and EF1- $\alpha$ genes was studied using the partition homogeneity tests with the aid of PAUP v.4.0b10 (28). The sequence of Cylindrocladiella peruviana was used as outgroup. Terminal regions that did not provide data from every sequence were excluded from the analysis. The maximum parsimony analysis using the close-neighbor-interchange on random trees search option was used with the aid of MEGA v. 5.05 (29). Bootstrap support values with 1,000 replications were calculated for tree branches, with 10 random sequence additions in each of 1,000 pseudoreplicates.

Table 1. Isolates of Diaporthe spp. obtained from commercial blueberry (Vaccinium spp.) plantings in Chile

\begin{tabular}{|c|c|c|c|c|c|c|}
\hline \multirow[b]{2}{*}{ Species $^{\mathrm{w}}$} & \multirow[b]{2}{*}{ Locality } & \multirow[b]{2}{*}{ Latitude $^{x}$} & \multirow[b]{2}{*}{ Blueberry $^{\mathrm{y}}$} & \multicolumn{2}{|c|}{ GenBank accession number ${ }^{v}$} & \multirow[b]{2}{*}{$\mathbf{I M I}^{\mathbf{z}}$} \\
\hline & & & & ITS & EF1- $\alpha$ & \\
\hline \multicolumn{7}{|c|}{ Diaporthe ambigua } \\
\hline 10.3.2.01 & Nancagua & $34^{\circ} 40^{\prime}$ & Duke & KC143171 & $\ldots$ & 500618 \\
\hline 10.3.3.02 & Nancagua & $34^{\circ} 40^{\prime}$ & O'Neal & KC143172 & $\ldots$ & 501896 \\
\hline 11.1.1.01 & Ovalle & $30^{\circ} 36^{\prime}$ & Jewell & KC143173 & КС533434 & 500618 \\
\hline 11.1.1.02 & Ovalle & $30^{\circ} 36^{\prime}$ & Jewell & KC143174 & $\ldots$ & $\ldots$ \\
\hline \multicolumn{7}{|c|}{ D. australafricana } \\
\hline 07.2 .1 .01 & Santiago & $33^{\circ} 27^{\prime}$ & Jewell & KC143190 & КC533436 & 501902 \\
\hline 10.3.3.01 & Nancagua & $34^{\circ} 40^{\prime}$ & O'Neal & KC143180 & KC533435 & 501895 \\
\hline 10.5.1.01 & Los Angeles & $37^{\circ} 23^{\prime}$ & Liberty & KC143183 & $\ldots$ & 501899 \\
\hline 10.5.2.01 & Los Angeles & $37^{\circ} 23^{\prime}$ & O'Neal & KC143184 & $\ldots$ & $\ldots$ \\
\hline 11.5.3.01 & Los Angeles & $37^{\circ} 23^{\prime}$ & Brigitta & KC143187 & KC533437 & 500619 \\
\hline 07.5.4.01 & Los Angeles & $37^{\circ} 23^{\prime}$ & Duke & KC143191 & KC533438 & 501901 \\
\hline 10.6.1.02 & Valdivia & $39^{\circ} 48^{\prime}$ & Blue Ray & KC143177 & & 500060 \\
\hline 11.6.1.01 & Valdivia & $39^{\circ} 48^{\prime}$ & Bluecrop & KC143178 & KC533441 & 500614 \\
\hline 11.6.1.02 & Valdivia & $39^{\circ} 48^{\prime}$ & Bluecrop & KC143175 & КС533440 & 500615 \\
\hline 11.6.1.06 & Valdivia & $39^{\circ} 48^{\prime}$ & Bluecrop & KC143186 & $\ldots$ & $\ldots$ \\
\hline 10.6.1.03 & Valdivia & $39^{\circ} 48^{\prime}$ & Elliot & KC143181 & $\ldots$ & $\ldots$ \\
\hline 10.6.1.04 & Valdivia & $39^{\circ} 48^{\prime}$ & Elliot & KC143176 & КС533439 & 500617 \\
\hline 10.6.1.05 & Valdivia & $39^{\circ} 48^{\prime}$ & Bluecrop & KC143179 & $\ldots$ & 500062 \\
\hline 10.6.1.08 & Valdivia & $39^{\circ} 48^{\prime}$ & Elliot & KC143182 & & $\ldots$ \\
\hline 10.6.2.01 & Valdivia & $39^{\circ} 48^{\prime}$ & Brigitta & KC143189 & KC533442 & $\ldots$ \\
\hline 11.6.3.01 & Valdivia & $39^{\circ} 38^{\prime}$ & Duke & KC143185 & $\ldots$ & $\ldots$ \\
\hline 07.7.1.01 & Osorno & $40^{\circ} 53^{\prime}$ & Liberty & KC143188 & $\ldots$ & 501900 \\
\hline \multicolumn{7}{|c|}{ D. neotheicola } \\
\hline 10.3.1.01 & Nancagua & $34^{\circ} 40^{\prime}$ & Brigitta & KC143192 & $\ldots$ & 500612 \\
\hline 11.4.1.01 & Chillán & $36^{\circ} 36^{\prime}$ & $\mathrm{Nd}$ & KC143193 & $\ldots$ & 501903 \\
\hline 11.6.1.04 & Valdivia & $39^{\circ} 48^{\prime}$ & Blue Ray & KC143194 & $\ldots$ & 501898 \\
\hline 11.6.1.05 & Valdivia & $39^{\circ} 48^{\prime}$ & Blue Ray & KC143195 & КС533443 & $\ldots$ \\
\hline \multicolumn{7}{|c|}{ D. passiflorae } \\
\hline 11.6.1.03 & Valdivia & $39^{\circ} 48^{\prime}$ & Blue Ray & KC143196 & KC533444 & 501897 \\
\hline 11.6.1.09 & Valdivia & $39^{\circ} 48^{\prime}$ & Blue Heaven & KC143198 & KC533445 & $\ldots$ \\
\hline 10.6.1.06 & Valdivia & $39^{\circ} 48^{\prime}$ & Bluecrop & KC143197 & $\ldots$ & 500061 \\
\hline \multicolumn{7}{|c|}{ Diaporthe sp. 1} \\
\hline 10.6.1.01 & Valdivia & $39^{\circ} 48^{\prime}$ & Blue Ray & KC143200 & КС533446 & 500616 \\
\hline 10.6.1.07 & Valdivia & $39^{\circ} 48^{\prime}$ & Bluecrop & KC143199 & KC533447 & 500059 \\
\hline
\end{tabular}

${ }^{\mathrm{v}}$ ITS $=$ internal transcribed spacer and $\mathrm{EF} 1-\alpha=$ translation elongation factor $1-\alpha$.

${ }^{w}$ Code numbers represent year of isolation/geographical location/orchard/isolate number.

${ }^{\mathrm{x}}$ Southern latitude.

${ }^{y}$ Blue Heaven, Blue Ray, Bluecrop, Brigitta, Duke, Elliot, and Liberty are northern high-bush blueberry cultivars (Vaccinium corymbosum), and cultivars Jewell and O'Neal are southern high-bush blueberry cultivars (V. corymbosum $\times$ V. darrowi).

${ }^{\mathrm{z}}$ International Mycological Institute (IMI) number; CABI, CABI Bioscience Genetic Resource Collection, Surrey, UK. 
Effect of temperature on mycelial growth. To determine the effect of temperature on the mycelial growth of $D$. australafricana ( $n=3$ isolates), D. ambigua ( $n=2$ isolates), D. neotheicola $(n=2$ isolates), D. passiflorae ( $n=1$ isolate), and Diaporthe sp. 1 ( $n=2$ isolates), a 5-mm-diameter mycelial plug was placed on APDA and incubated in thermal chambers (Velp Scientifica) adjusted to 0 to $40^{\circ} \mathrm{C}\left( \pm 1^{\circ} \mathrm{C}\right)$ in $5^{\circ} \mathrm{C}$ intervals. The temperature inside the chambers was checked with a HOBO PRO temperature sensor (Onset Computer Corp.). The radius of the mycelial growth was determined after 2 to 4 days in darkness. This experiment was conducted twice.

Pathogenicity studies on blueberry. Mature fruit (mean soluble solids of $12.5 \%)$ of harvested blueberry ('O'Neal') $(n=4)$ were surface disinfected in $75 \%$ ethanol for $5 \mathrm{~min}$, then rinsed in sterile water and air dried. A 3-mm-diameter mycelial plug taken from 7day-old cultures grown on APDA was placed over three punctures aseptically made with the aid of a hypodermic needle. Fruit were incubated for 6 days at $20^{\circ} \mathrm{C}$ in a humid chamber $(100 \%$ relative humidity $[\mathrm{RH}]$ ) before the diameters of the lesions were determined. An equal number of fruit treated with sterile agar plugs served as the controls. This test was repeated.

Detached, actively growing shoots $(<1$ year old; $n=4)$ and dormant, partially lignified stems ( 1 to 2 years old; $n=4$ ) of blueberry (O'Neal) were inoculated in the laboratory. Stems (10 to 15 $\mathrm{cm}$ long) were surface disinfected (75\% ethanol, $5 \mathrm{~min}$ ), a cut was made in the middle, and a 5-mm-diameter agar plug was aseptically inserted under the epidermis. The inoculation sites were wrapped with Parafilm M (Pechiney Plastic Packaging). The stems were placed vertically in a humid chamber $(>90 \% \mathrm{RH})$ at $20^{\circ} \mathrm{C}$, with the end submerged in $3 \mathrm{~cm}$ of water. The length of the necrotic lesions was determined after 14 to 21 days of incubation. An equal number of stems treated with sterile agar plugs served as the controls. This test was repeated.

Attached stems of blueberry (O'Neal) were inoculated. For this purpose, nonlignified, <1-year-old shoots $(n=4)$ and partially lignified, 1- to 2-year-old stems $(n=4)$ were pruned aseptically and immediately inoculated with a mycelial plug $(5 \mathrm{~mm}$ in diameter) placed in the pruned stub and wrapped with Parafilm. The lesion that developed from the inoculation site was examined after 21 days. An equal number of stems treated with sterile agar plugs served as the controls.

Pathogenicity studies on other hosts. To evaluate the ability of Diaporthe isolates to infect hosts other than blueberry, detached shoots $(<1$ year old) of 'Granny Smith' apple and the 'Packham's Triumph' pear and attached shoots $(<1$ year old) of 'Thompson Seedless' grapevines were surface disinfected, injured, and inoculated as described above. Detached inoculated stems were incubated in a humid chamber at $20^{\circ} \mathrm{C}$ for 14 days prior to measurement of the length of the necrotic lesions. The attached shoots of grapevines were inoculated, wrapped with Parafilm, and left for 28 days before the length of the vascular necrotic lesions was determined.

To fulfill Koch's postulates, small pieces ( $5 \mathrm{~mm}$ in length) of diseased tissue from the margins of the necrotic lesions were placed on APDA. The causal agents were reidentified based on their colony and conidial morphologies.

Design and statistical analysis. The temperature treatments were performed in a completely randomized design, with five replicates each of one Petri plate. Fruit pathogenicity studies were performed in a completely randomized design, using five blueberry fruit as the experimental unit. Blueberry inoculations were performed using an eight-by-two (isolates by age of the inoculated tissue) factorial design, with four replicates each of one stem being an experimental unit. Pathogenicity studies conducted on other host stems were performed in a completely randomized design, with four replicates each of one stem. The results were subjected to an analysis of variance and the means were applied using Tukey's test $(P<0.05)$ on SigmaStat 3.1 software (Systat Software Inc.).

\section{Results}

Sampling locations and fungal isolation. In total, 30 isolates of Diaporthe spp. were obtained from diseased 'Bluecrop', 'Blue Heaven', 'Blueray', 'Brigitta', 'Duke', 'Elliot', 'Liberty', 'Jewell', and O'Neal blueberry (Table 1). The symptoms of fungal infection were apical necrosis, reddish-brown cankers at the base of the stems and crowns, partially dehydrated twigs, and internal darkbrown vascular damage. Often, necrotic stem lesions turned whit-

Table 3. Effect of incubation temperature on the development of fertile perithecia and pycnidia of Diaporthe spp. growing on autoclaved stems of alfalfa and blueberry placed on $2 \%$ water $\operatorname{agar}^{\mathrm{z}}$

\begin{tabular}{lccccc}
\hline & \multicolumn{2}{c}{ Number of perithecia } & & \multicolumn{2}{c}{ Number of pycnidia } \\
\cline { 6 - 6 } \cline { 5 - 6 } Temperature $\left({ }^{\circ} \mathbf{C}\right)$ & Alfalfa & Blueberry & & Alfalfa & Blueberry \\
\hline Diaporthe ambigua & & & & & \\
5 & $0 / 4$ & $0 / 4$ & & $2 / 4$ & $3 / 4$ \\
10 & $1 / 4$ & $4 / 4$ & & $4 / 4$ & $4 / 4$ \\
20 & $0 / 4$ & $2 / 4$ & & $0 / 4$ & $0 / 4$ \\
D. australafricana & & & & \\
5 & $0 / 15$ & $0 / 15$ & & $6 / 15$ & $1 / 15$ \\
10 & $5 / 15$ & $13 / 15$ & & $8 / 15$ & $2 / 15$ \\
20 & $0 / 15$ & $0 / 15$ & & $0 / 15$ & $1 / 15$ \\
D. neotheicola & & & & \\
5 & $0 / 4$ & $0 / 4$ & & $4 / 4$ & $1 / 4$ \\
10 & $0 / 4$ & $0 / 4$ & & $4 / 4$ & $4 / 4$ \\
20 & $0 / 4$ & $0 / 4$ & & $0 / 4$ & $2 / 4$ \\
D. passiflorae & & & & \\
5 & $0 / 3$ & $0 / 3$ & & $1 / 3$ & $0 / 3$ \\
10 & $0 / 3$ & $0 / 3$ & & $1 / 3$ & $1 / 3$ \\
20 & $0 / 3$ & $0 / 3$ & & $0 / 3$ & $0 / 3$ \\
Diaporthe sp. 1 & & & & \\
5 & $0 / 2$ & $0 / 2$ & & $2 / 2$ & $1 / 2$ \\
10 & $0 / 2$ & $0 / 2$ & & $1 / 2$ & $1 / 2$ \\
20 & $0 / 2$ & $0 / 2$ & $0 / 2$ & $0 / 2$ \\
\hline
\end{tabular}

${ }^{\mathrm{z}}$ Cultures were incubated for 14 days at room temperature $\left(20\right.$ to $\left.22^{\circ} \mathrm{C}\right)$ prior to incubating them at 5,10 , or $20^{\circ} \mathrm{C}$ for 60 to 90 days. Only perithecia and pycnidia containing spores were considered fertile. Data shown are number of isolates that produced perithecia or pycnidia/total number of isolates tested.

Table 2. Internal transcribed spacer (ITS) accession numbers in GenBank of Diaporthe isolates used for phylogenetic analyses in this study

\begin{tabular}{|c|c|c|c|c|c|}
\hline \multirow[b]{2}{*}{ Species } & \multicolumn{2}{|c|}{ GenBank accession number ${ }^{\mathrm{z}}$} & \multirow[b]{2}{*}{ Origin } & \multirow[b]{2}{*}{ Host } & \multirow[b]{2}{*}{ Reference } \\
\hline & ITS & EF1- $\alpha$ & & & \\
\hline Cylindrocladiella peruviana & AY793459 & AY725736 & South Africa & Vitis vinifera & 3 \\
\hline Diaporthe ambigua & AF230767 & GQ250299 & South Africa & Pyrus communis & 23 \\
\hline D. australafricana & AF230760 & na & Australia & Vitis vinifera & 33 \\
\hline D. australafricana & AF230744 & na & South Africa & Vitis vinifera & 33 \\
\hline D. australafricana & JQ045712 & na & Chile & Vaccinium corymbosum & 16 \\
\hline D. neotheicola & DQ286286 & DQ286260 & South Africa & Aspalathus linearis & 34 \\
\hline D. neotheicola & EU814480 & GQ250315 & Portugal & Foeniculum vulgare & 22,23 \\
\hline D. passiflorae & JX069860 & na & South America & Passiflora edulis & 5 \\
\hline D. phaseolorum & HM347705 & HM347679 & Croatia & Arctium lappa & 22 \\
\hline D. phaseolorum & JQ619876 & JX275390 & Thailand & Hylocerus undatus & 32 \\
\hline D. vaccinii & AY952141 & GQ250326 & United States & Vaccinium macrocarpon & 23 \\
\hline
\end{tabular}

z Abbreviation: na = sequences not available in GenBank. 
ish and abundant black pycnidia were observed on the dead tissue. Symptoms were frequently associated with the presence of pruning wounds and extended several centimeters below the wounds. $D i$ aporthe spp. were isolated alone (53\%) and co-isolated (47\%) with species of Botryosphaeriaceae (38\%) and Pestalotiopsis (9\%).

Identification and characterization of the isolates. On APDA, all Diaporthe isolates produced flat, white-to-creamy-colored colonies, and 13 isolates developed pycnidia after 40 to 60 days at $20^{\circ} \mathrm{C}$. PCR amplification and DNA sequencing included the 590to 610 -bp products of the ITS1 and ITS2 regions, which include the conserved $5.8 \mathrm{~S}$ region of the ITS gene. The sequences were aligned with the ITS sequences of ex-type isolates of Diaporthe deposited in GenBank (Table 2). BLAST search showed $>98 \%$ similarity of the Chilean isolates of Diaporthe spp. with ex-type isolates of D. ambigua Nitschke, D. australafricana Crous \& Van Niekerk, D. neotheicola A.J.L. Phillips \& J.M. Santos, and D. passiflorae Crous \& L. Lombard. In addition, a nonidentifiable isolate, Diaporthe sp. 1, was obtained (Table 1).

Fertile perithecia of isolates of D. ambigua and D. australafricana were observed after the isolates had grown on APDA plates

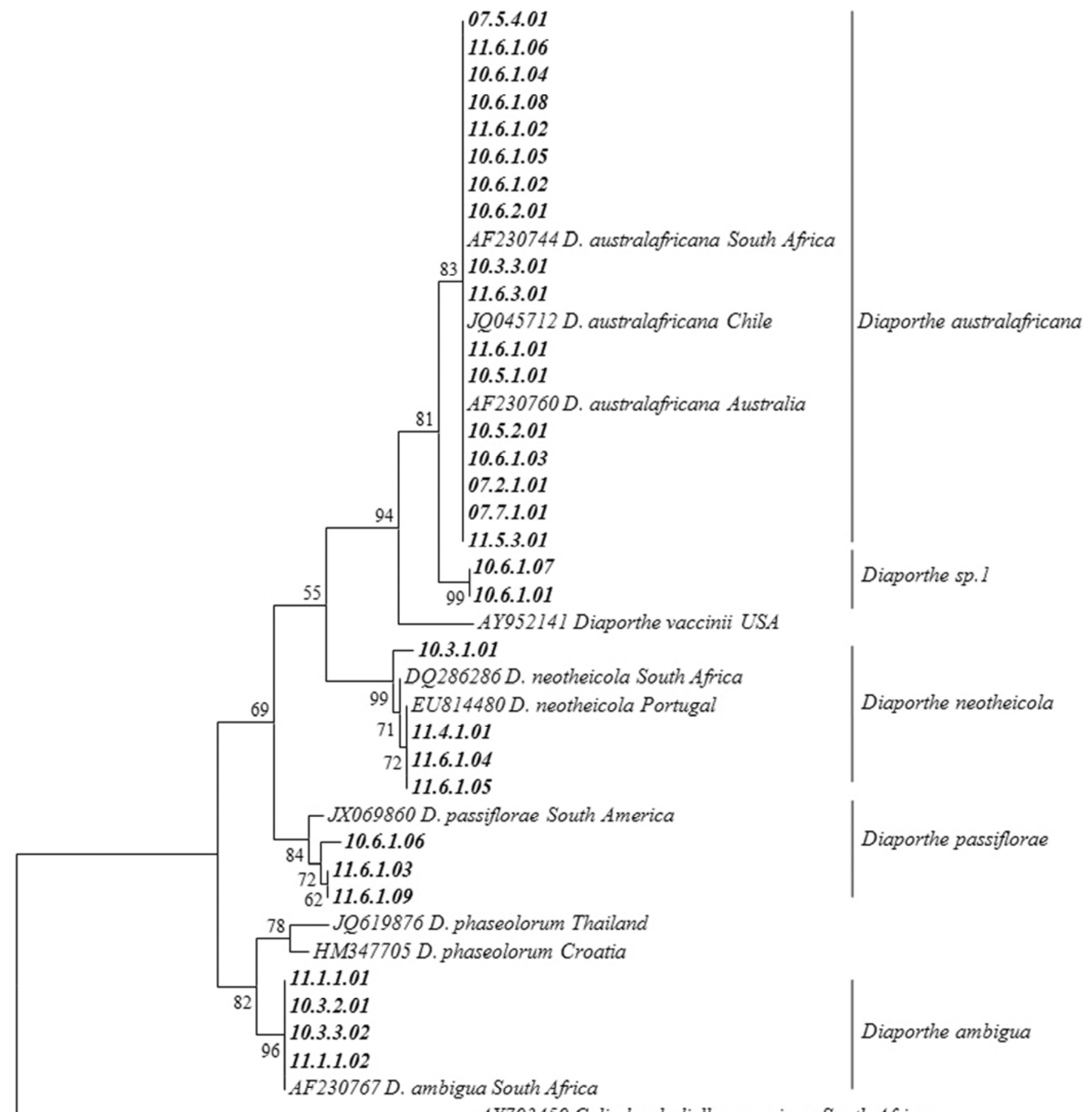
AY793459 Cylindrocladiella peruviana South Africa

10

Fig. 1. Phylogram obtained from a parsimony analysis of ribosomal DNA internal transcribed spacer of sequences of new Diaporthe isolates from the Chilean blueberry and from sequences of ex-types in GenBank. Shown is 1 of 376 equally most parsimonious trees and bootstrap values.. The tree was rooted with Cylindrocladiella peruviana (AY793459). Tree length $=205$, consistency index $=0.795$, retention index $=0.915$, rescaled consistency index $=0.728$. Code numbers in bold are Diaporthe isolates from blueberry in Chile; other codes are the GenBank accessions numbers. 
for 40 to 60 days at 20 to $22^{\circ} \mathrm{C}$. Perithecia were observed on autoclaved alfalfa and blueberry stems after 70 to 90 days at 10 but not at $5^{\circ} \mathrm{C}$, and only two isolates of $D$. ambigua formed perithecia at $20^{\circ} \mathrm{C}$ (Table 3 ). The perithecia were black, globose, solitary, scattered, or aggregated, with a subepidermal origin. The perithecial necks were long, brown to dark-brown, and tapered toward the apex, with a red-brown ostiole that was smooth in D. ambigua and partially covered with external hyphae in $D$. australafricana. The asci were unitunicate, cylindrical, provided with a refractive apical ring and 8-biseriate ascospores, hyaline, fusoid, medially tapering toward both ends, septated, and widest at the septum, with two distinctive guttules. The ascospores of $D$. ambigua were 11.6 to 13.7 by 3.5 to $4.2 \mu \mathrm{m}$ (average of $n=4$ isolates) and ascospores of D. australafricana were 12.4 to 14.1 by 3.6 to $4.7 \mu \mathrm{m}$ (average of $n=15$ isolates). Ascospore appendages were not observed. Ascospores were not observed in vitro or in vivo for isolates of $D$. neotheicola, D. passiflorae, and Diaporthe sp. 1 (Table 3).

Of the 30 isolates, 13 formed $\alpha$-conidia in globose black pycnidia on APDA, 19 of 28 isolates formed pycnidia on autoclaved stems of alfalfa, and 10 of 28 isolates formed pycnidia on autoclaved blueberry stems. The $\alpha$-conidia were born in short hyaline conidiophores and were always hyaline, one-celled, and biguttulate. D. ambigua produced 6.1- to 7.1- by 2.8- to 3.0- $\mu$ m ellipsoidal $\alpha$-conidia, with obtuse ends and a visible scar at the base (average of $n=4$ isolates). D. australafricana produced 5.7- to 7.3- by 2.3- to 3.1- $\mu \mathrm{m}$ ellipsoidal to fusoid $\alpha$-conidia with obtuse ends and a visible scar at the base (average of $n=12$ isolates). D. neotheicola produced 6.4- to 7.6- by 2.1 - to $2.5-\mu \mathrm{m}$ fusoid $\alpha$-conidia with obtuse ends and a visible scar at the base (average of $n=3$ isolates). D. passiflorae produced 6.4 - to 7.0 - by 2.1 - to $2.3-\mu \mathrm{m}$ ellipsoidal to fusoid $\alpha$-conidia with tapering ends and guttules that were either prominent or diffuse (average of $n=2$ isolates), and Diaporthe sp. 1 produced 7.8 - by $2.9-\mu$ m ellipsoidal to fusoid $\alpha$ conidia with obtuse ends and a visible scar at the base. $\beta$-Conidia were absent in D. ambigua, D. australafricana, and Diaporthe sp. 1. Nonseptated 24.6 - to 28.7 - by 1.2 - to $1.4-\mu \mathrm{m} \beta$-conidia that were hyaline, filiform, uncinate, and eggutulate with rounded ends were produced by $D$. neotheicola (average of $n=4$ isolates). Similar 25.9 - to 29.9 - by 1.2 - to 1.5 - $\mu \mathrm{m} \beta$-conidia but spindle shaped or filiform were formed by $D$. passiflorae. $\gamma$-Conidia were observed in isolates of $D$. passiflorae.

Phylogenetic analysis. Phylogenetic analysis was done using DNA sequences of a region of the ITS consisting of approximately 447 nucleotides. The alignment included sequences from the 30 Chilean isolates and 10 Diaporthe sequences from ex-type cultures deposited in GenBank, with $C$. peruviana as the outgroup (Table 2 ). Due to the inclusion of sequences from GenBank that were shorter on the $5^{\prime}$ and $3^{\prime}$ ends, the complete sequences determined in this study were not used in the phylogenetic analysis. Maximum parsimony analysis (Fig. 1) yielded 376 most parsimonious trees (tree length $[\mathrm{TL}]=205$, consistency index $[\mathrm{CI}]=0.795$, retention index $[\mathrm{RI}]=0.915$, and rescaled consistency index $[\mathrm{RC}]=0.728)$. The phylogenetic tree delimited five main clades (Fig. 1). Clade I, with $83 \%$ bootstrap support, contains identical sequences of isolates of D. australafricana from the Chilean blueberry that were grouped together with D. australafricana isolates (AF230760 and AF230744) from grapevines in Australia and South Africa (25) and with a previously reported $D$. australafricana isolate (JQ045712) from the Chilean blueberry (14). Clade II, with 99\% bootstrap support, contains nonidentified isolates of Diaporthe sp. 1 related to D. australafricana but which are presumably heterothallic due to the absence of perithecia in their hyphal tips. Clade III, with $99 \%$ bootstrap support, grouped isolates identified as D. neotheicola together with $D$. neotheicola from rooibos and fennel from South Africa and Portugal, respectively. Clade IV, with $84 \%$ bootstrap support, grouped three Chilean isolates together with $D$. passiflorae isolate JX069860 from South American passion fruit. Clade V, with $96 \%$ bootstrap support, grouped almost identical sequences of Chilean isolates identified as D. ambigua together with D. ambigua isolate AF230767, from a South African pear. The reference sequence of $D$. vaccinii (isolate AY952141) from Vaccinium spp. from the United States was grouped separately from all the Chilean isolates found in this study. Similarly, sequences of reference isolates of D. phaseolorum were grouped separately (Fig. 1).

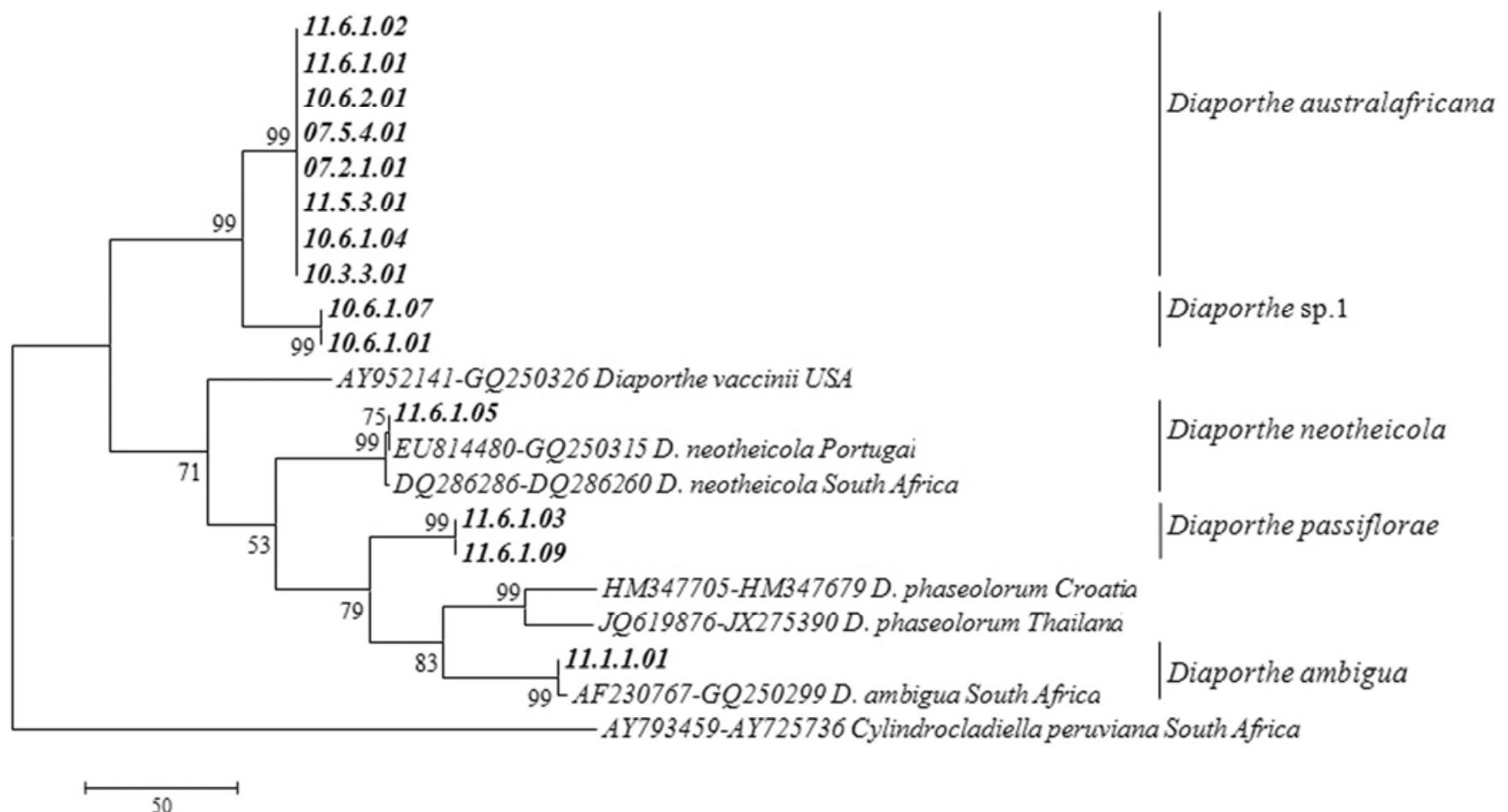

Fig. 2. Phylogram obtained from a parsimony analysis of the combined internal transcribed spacer (ITS) and translation elongation factor $1-\alpha$ (EF1- $\alpha$ ) alignment of sequences of new Diaporthe isolates from the Chilean blueberry and from sequences of ex-types in GenBank. Shown is 1 of 130 equally most parsimonious trees and bootstrap values. The tree was rooted with Cylindrocladiella peruviana (AY793459 and AY72736). Tree length $=640$, consistency index $=0.757$, retention index $=0.851$, rescaled consistency index $=0.758$. Code numbers in bold are Diaporthe isolates from blueberry in Chile; other codes are the GenBank accession numbers (ITS and EF1- $\alpha$ ). 
The partitioned homogeneity test indicates no major differences between the ITS and EF1- $\alpha$ genes $(P>0.05)$, allowing us to analyze both genes together. The combined phylogenetic analysis using the rDNA sequences of ITS and EF1- $\alpha$ consisted of approximately 780 nucleotides. The alignment included 14 sequences of the Chilean isolates and six sequences from GenBank, with $C$. peruviana as outgroup. Maximum parsimony analysis (Fig. 2) of the alignment yielded 130 most-parsimonious trees $(\mathrm{TL}=640, \mathrm{CI}$ $=0.757, \mathrm{RI}=0.851, \mathrm{RC}=0.758)$. The same five main clades that were delimited in the ITS tree (Fig. 1) were found in the combined phylogenetic analysis.

Effect of temperature on mycelial growth. The mycelial growth of the Diaporthe isolates was significantly affected by temperature $(P<0.001)$. The interaction between the temperature and the isolate type was significant $(P<0.001)$. The isolates of $D$. ambigua grew at temperatures between 5 and $35^{\circ} \mathrm{C}$, whereas the isolates of D. australafricana, D. neotheicola, and D. passiflorae grew between 10 and $30^{\circ} \mathrm{C}$ and the isolates of Diaporthe sp. 1 grew between 5 and $30^{\circ} \mathrm{C}$. For isolates of $D$. australafricana, $D$. passiflorae, and Diaporthe sp. 1, optimal mycelial growth was obtained at $20^{\circ} \mathrm{C}$, whereas it was between 25 and $30^{\circ} \mathrm{C}$ for $D$. ambigua isolates and at $25^{\circ} \mathrm{C}$ for D. neotheicola (Fig. 3).

The isolates of D. ambigua were the fastest growing, with a radial growth of 48 to $30 \mathrm{~mm}$ per $48 \mathrm{~h}$ at $25^{\circ} \mathrm{C}$, followed by $D$. passiflorae $(29 \mathrm{~mm}$ per $48 \mathrm{~h}$ ), isolates of D. australafricana (27 to 17 $\mathrm{mm}$ per $48 \mathrm{~h}$ ) and D. neotheicola (20 to $19 \mathrm{~mm}$ per $48 \mathrm{~h}$ ), and finally isolates of Diaporthe sp. 1 ( $<14 \mathrm{~mm}$ per $48 \mathrm{~h}$ ). The differences in the mycelial growth rate among the Diaporthe isolates were significant $(P<0.001)$. Significant differences in the mycelial growth rate at $25^{\circ} \mathrm{C}$ were observed by isolates of $D$. ambigua and D. australafricana (Fig. 4).

Pathogenicity studies on blueberry. All isolates of Diaporthe spp. developed a light-brown, watery, soft decay that partially comprised the fruit by 6 days post inoculation. Isolates had a significant effect $(P=0.021)$ on percent fruit rot, which varied from 5.7 to $39.3 \%$; D. australafricana (isolate 07.7.1.01) was the most virulent isolate and D. ambigua was the least virulent isolate (Table 4). No symptoms were observed in the noninoculated controls. Reisolations were successfully accomplished for $100 \%$ of the inoculated fruit.

Reddish-brown necrotic lesions were observed in detached, actively growing shoots and in detached dormant, partially lignified blueberry stems. Internally, the lesions were characterized by a light-brown vascular discoloration with a mean length of 9.5 to $42.2 \mathrm{~mm}$ in shoots and 7.3 to $15.3 \mathrm{~mm}$ in stems (Table 4). Reisolations were successful from $96.9 \%$ of the inoculated stems. Isolates and the age of the inoculated blueberry stems showed a significant

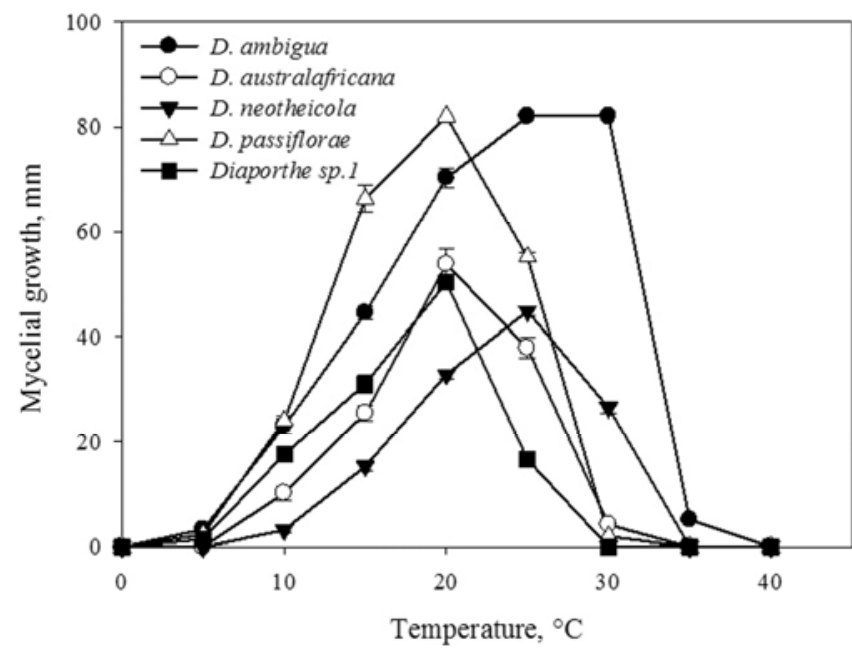

Fig. 3. Effect of temperature on the mean radial mycelial growth of Diaporthe ambigua, D. australafricana, D. neotheicola, D. passiflorae, and Diaporthe sp. 1 after 4 days on acidified potato dextrose. Vertical bars $=$ standard errors. interaction $(P<0.001)$ but this was observed only when the isolates had been inoculated into detached blueberry stems (Table 4).

Based on pathogenicity studies with blueberry shoots, significant differences in virulence were observed among species and isolates of Diaporthe. The most virulent isolates were D. passiflorae isolate 10.6.1.06 and D. australafricana isolates 11.6.1.02 and 07.7.1.01. Similarly, D. australafricana isolates 11.6.1.02, 07.7.1.01, and 11.5.3.01 and D. passiflorae isolate 10.6.1.06 were the most virulent isolates for blueberry stems. There was a significant $(P<0.001)$ relationship between the effects of the isolates and the type of tissue inoculated, shoots or dormant stems. Shoots were more susceptible than dormant stems (Table 4).

Without exception, the Diaporthe isolates were pathogenic in attached shoots and stems of mature O'Neal blueberry established in the ground (Table 4). The symptoms consisted of reddish-brown necrotic lesions 2.8 to $16.2 \mathrm{~mm}$ in length that partially comprised the internal tissues, causing vascular discoloration. Isolates and the age of the blueberry tissue (shoots and stems) had a significant effect on the necrotic lesions observed but the interaction between isolates and the age of the blueberry tissue was not significant (Table 4). Significant differences in the length of the necrotic lesions were found, with $D$. ambigua being the most virulent isolate. Reisolations were successfully accomplished for $93.8 \%$ of the diseased blueberry plants.

Pathogenicity studies on other hosts. Diaporthe isolates were pathogenic for the detached shoots of apple and pear (Table 5). The symptoms included reddish-brown necrotic lesions within the stems and a light-brown vascular discoloration with a mean length of 7.1 to 11.9 and 8.9 to $14.2 \mathrm{~mm}$ in apple and pear, respectively (Table 5). Reisolations from $73.3 \%$ of the apple stems and $50.0 \%$ of the pear stems were successfully accomplished.

All Diaporthe isolates were pathogenic for the attached grapevine shoots, in which dark-brown necrotic lesions and 10.4- to 35.7-mm-long vascular discolorations, developed by 28 days post inoculation. Reisolations from $72.2 \%$ of the inoculated grapevine stems were successfully accomplished from discolored vascular tissues.

\section{Discussion}

This study constitutes the first attempt to characterize the species of Diaporthe associated with stem canker and dieback of blueberry in Chile, which was previously only associated with species

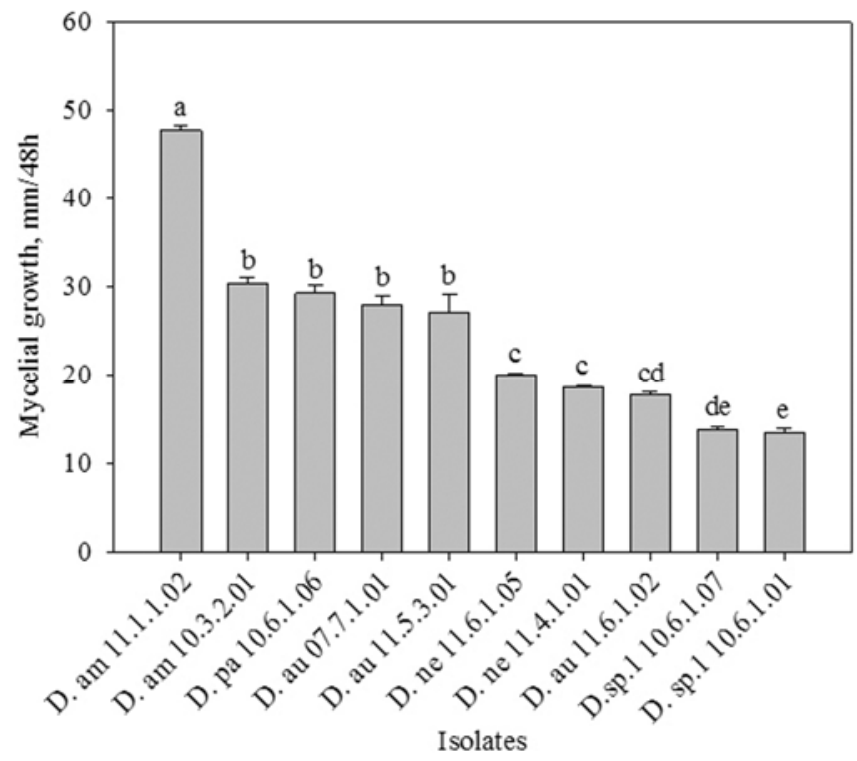

Fig. 4. Mean mycelial growth rate of Diaporthe ambigua (D. am), D. australafricana (D. au), D. neotheicola (D. ne), D. passiflorae (D. pa), and Diaporthe sp. 1 (D. sp. 1) after $48 \mathrm{~h}$ of incubation at $25^{\circ} \mathrm{C}$ on acidified potato dextrose agar. Means followed by the same letters are not significantly different according to Tukey's test $(P=$ 0.05). . Vertical bars = standard errors. 
of Botryosphaeriaceae and Pestalotiopsis (6,7). Four species of Diaporthe were identified, which included D. ambigua, D. australafricana, D. neotheicola, D. passiflorae, and Diaporthe sp. 1, a nonidentified species.

As previously proposed for the identification of Diaporthe (Phomopsis) complex (23), the blueberry isolates of Diaporthe were successfully identified with ITS sequence analysis combined with morphological characteristics. However, morphological characteristics alone were insufficient to delimit these species of $\mathrm{Di}$ aporthe.

Because of the unavailability of known sequences for the EF1- $\alpha$ gene in GenBank, it was impossible to identify all Chilean isolates using the sequence data from the two intron regions of the EF1- $\alpha$ gene. Nevertheless, the concatenated analysis using ITS and EF1- $\alpha$ gene sequences grouped the Chilean blueberry isolates in five groups that corresponded to the species identified on the basis of the ITS analysis.

Although the ITS and EF1- $\alpha$ analyses and the combined ITS and EF1- $\alpha$ phylogenetic analyses showed Diaporthe isolates from blueberry to share $>98 \%$ similarity with previously identified $\mathrm{Di}$ aporthe (Phomopsis) spp., isolates named Diaporthe sp. 1 differed from the rest of Diaporthe (Phomopsis) spp. available in GenBank. These isolates are potential novel species within this genus; however, additional studies are needed to confirm the identity of the Diaporthe sp. 1 isolates.

All the Diaporthe spp. identified in this study were previously reported on other host plants, suggesting the invalidity of using host association criteria to identify the species of Diaporthe in blueberry, as has been discussed for other hosts $(2,8,19,24,32-34)$.
Similar to a previous study conducted on V. vitis-idaea (lingonberry) (8), it demonstrated that several species of Diaporthe can be associated with blueberry stem cankers, acting alone or together.

Table 5. Pathogenicity of Diaporthe spp. isolates obtained from the blueberry on detached shoots of 'Granny Smith' apple, 'Thompson Seedless' grapevine, and 'Packham's Triumph' pear

\begin{tabular}{lccc}
\hline & \multicolumn{3}{c}{ Length of shoot cankers $(\mathbf{m m})^{\mathbf{x}}$} \\
\cline { 2 - 4 } Species & Apple $^{\mathbf{y}}$ & Grapevine $^{\mathbf{z}}$ & Pears $^{\mathbf{y}}$ \\
\hline Diaporthe ambigua & & & \\
10.3.2.01 & $11.9 \mathrm{~ns}$ & $21.7 \mathrm{abc}$ & $12.3 \mathrm{~ns}$ \\
$\begin{array}{l}\text { D. australafricana } \\
\text { 11.6.1.02 }\end{array}$ & 9.5 & $10.8 \mathrm{c}$ & 11.3 \\
11.5.3.01 & 7.1 & $35.7 \mathrm{a}$ & 8.9 \\
07.7.1.01 & 100 & $27.0 \mathrm{ab}$ & 11.5 \\
$\begin{array}{l}\text { D. neotheicola } \\
\text { 10.3.1.01 }\end{array}$ & 10.8 & $16.3 \mathrm{bc}$ & 14.2 \\
$\begin{array}{l}\text { D. passiflorae } \\
\text { 10.6.1.06 }\end{array}$ & 9.5 & $13.1 \mathrm{bc}$ & 12.3 \\
$\begin{array}{l}\text { Diaporthe sp. 1 } \\
\text { 10.6.1.01 }\end{array}$ & 9.6 & $10.4 \mathrm{c}$ & 10.9 \\
\hline
\end{tabular}

${ }^{\mathrm{x}}$ No symptoms were observed in the noninoculated controls; these data were excluded from the statistical analysis. Means followed by the same letter in each column did not differ significantly according to Tukey's pairwise multiple comparison test $(P=0.05)$; ns $=$ not significant at $P=0.05$.

${ }^{y}$ Data were recorded after 14 days of incubation in a humid chamber at $20^{\circ} \mathrm{C}$ after inoculation with mycelia on fruit and detached stem, respectively.

${ }^{\mathrm{z}}$ Data were recorded after 28 days on attached stems after inoculation with mycelia.

Table 4. Pathogenicity of Diaporthe spp. on stems and mature fruit of blueberry ('O'Neal') and the effect of the age of the stems on the necrotic lesions

\begin{tabular}{|c|c|c|c|c|c|c|c|c|c|c|}
\hline \multirow[b]{3}{*}{ Species } & \multicolumn{8}{|c|}{ Length of cankers $(\mathbf{m m})^{v}$} & \multirow[b]{3}{*}{ Fruit $(\%)^{y}$} & \multirow[b]{3}{*}{ ANOVA } \\
\hline & \multicolumn{4}{|c|}{ Detached stems ${ }^{w}$} & \multicolumn{4}{|c|}{ Attached stems $^{x}$} & & \\
\hline & $<1$ year & 1-2 years & Mean & ANOVA & $<1$ year & 1-2 years & Mean & ANOVA & & \\
\hline \multicolumn{11}{|c|}{ Diaporthe ambigua } \\
\hline 10.3 .2 .01 & $26.7 \mathrm{ab}$ & $7.3 \mathrm{~b}$ & 17.0 & $\ldots$ & 23.2 & 9.3 & $16.2 \mathrm{a}$ & $\ldots$ & $5.7 \mathrm{~b}$ & $\ldots$ \\
\hline \multicolumn{11}{|c|}{ D. australafricana } \\
\hline 11.6.1.02 & $41.7 \mathrm{a}$ & $15.3 \mathrm{a}$ & 28.5 & $\ldots$ & 6.9 & 5.1 & $6.0 \mathrm{bc}$ & $\ldots$ & $33.7 \mathrm{ab}$ & $\ldots$ \\
\hline 11.5.3.01 & $28.5 \mathrm{ab}$ & $12.1 \mathrm{a}$ & 20.3 & $\ldots$ & 5.8 & 3.8 & $4.8 \mathrm{bc}$ & $\ldots$ & $23.5 \mathrm{ab}$ & $\ldots$ \\
\hline 07.7.1.01 & $37.5 \mathrm{a}$ & $13.2 \mathrm{a}$ & 25.3 & $\ldots$ & 10.4 & 5.6 & $8.0 \mathrm{~b}$ & $\ldots$ & $39.3 \mathrm{a}$ & $\ldots$ \\
\hline \multicolumn{11}{|c|}{ D. neotheicola } \\
\hline 10.3.1.01 & $9.5 \mathrm{~b}$ & $10.2 \mathrm{ab}$ & 9.9 & $\ldots$ & 6.8 & 3.6 & $5.2 \mathrm{bc}$ & $\ldots$ & $31.1 \mathrm{ab}$ & $\ldots$ \\
\hline \multicolumn{11}{|c|}{ D. passiflorae } \\
\hline 10.6.1.06 & $42.2 \mathrm{a}$ & $10.9 \mathrm{a}$ & 26.5 & $\ldots$ & 7.8 & 4.3 & $6.0 \mathrm{bc}$ & $\ldots$ & $11.8 \mathrm{ab}$ & $\ldots$ \\
\hline \multicolumn{11}{|c|}{ Diaporthe sp. 1} \\
\hline 10.6 .1 .01 & $21.5 \mathrm{ab}$ & $10.4 \mathrm{ab}$ & 16.0 & $\ldots$ & 3.0 & 2.6 & $2.8 \mathrm{c}$ & $\ldots$ & $9.3 \mathrm{ab}$ & \\
\hline Mean & 36.4 & 12.3 & $\ldots$ & $\ldots$ & $14.4 \mathrm{a}$ & $7.3 \mathrm{~b}$ & $\ldots$ & $\ldots$ & $\ldots$ & $\ldots$ \\
\hline \multicolumn{11}{|c|}{ ANOVA $^{z}$} \\
\hline \multicolumn{11}{|c|}{ Diaporthe isolates (DI) } \\
\hline $\mathrm{df}$ & $\ldots$ & $\ldots$ & $\ldots$ & 6 & $\ldots$ & $\ldots$ & $\ldots$ & 6 & $\ldots$ & 6 \\
\hline$F$ & $\ldots$ & $\ldots$ & $\ldots$ & 5.67 & $\ldots$ & $\ldots$ & $\ldots$ & 8.47 & $\ldots$ & 3.21 \\
\hline$P$ & $\ldots$ & $\ldots$ & $\ldots$ & $<0.001$ & $\ldots$ & $\ldots$ & $\ldots$ & $<0.001$ & $\ldots$ & 0.021 \\
\hline SED & $\ldots$ & $\ldots$ & $\ldots$ & 0.19 & $\ldots$ & $\ldots$ & $\ldots$ & 0.20 & $\ldots$ & 0.14 \\
\hline \multicolumn{11}{|c|}{ Age of tissue (AT) } \\
\hline df & $\ldots$ & $\ldots$ & $\ldots$ & 1 & $\ldots$ & $\ldots$ & $\ldots$ & 1 & $\ldots$ & $\ldots$ \\
\hline$F$ & $\ldots$ & $\ldots$ & $\ldots$ & 60.0 & $\ldots$ & $\ldots$ & $\ldots$ & 18.9 & $\ldots$ & $\ldots$ \\
\hline$P$ & $\ldots$ & $\ldots$ & $\ldots$ & $<0.001$ & $\ldots$ & $\ldots$ & $\ldots$ & $<0.001$ & $\ldots$ & $\ldots$ \\
\hline SED & $\ldots$ & $\ldots$ & $\ldots$ & 0.10 & $\ldots$ & $\ldots$ & $\ldots$ & 0.11 & $\ldots$ & $\ldots$ \\
\hline \multicolumn{11}{|c|}{ DI-AT interaction } \\
\hline df & $\ldots$ & $\ldots$ & $\ldots$ & 6 & $\ldots$ & $\ldots$ & $\ldots$ & 6 & $\ldots$ & $\ldots$ \\
\hline$F$ & $\ldots$ & $\ldots$ & $\ldots$ & 2.7 & $\ldots$ & $\ldots$ & $\ldots$ & 0.75 & $\ldots$ & $\ldots$ \\
\hline$P$ & $\ldots$ & $\ldots$ & $\ldots$ & 0.018 & $\ldots$ & $\ldots$ & $\ldots$ & 0.62 & $\ldots$ & $\ldots$ \\
\hline SED & $\ldots$ & $\ldots$ & $\ldots$ & 0.27 & $\ldots$ & $\ldots$ & $\ldots$ & 0.28 & $\ldots$ & $\ldots$ \\
\hline
\end{tabular}

${ }^{v}$ Cankers on stems $<1$ year old ( $<1$ year) and 1 to 2 years old (1-2 years). No symptoms were observed in the noninoculated controls; these data were excluded from the statistical analysis. Means followed by the same letter in each column did not differ significantly according to Tukey's pairwise multiple comparison test $(P=0.05)$.

${ }^{w}$ Detached actively growing <1-year-old shoots and dormant 1-2-year-old partially lignified stems The results were obtained after 14 to 21 days of incubation in a humid chamber at $20^{\circ} \mathrm{C}$.

x Attached <1-year-old, nonlignified shoots and 1-2-year-old stems, partially lignified from the previous growing season.

${ }^{y}$ Data were arcsine $\sqrt{ }(\mathrm{x} / 100)$ transformed before the analysis but the nontransformed data are presented.

${ }^{\mathrm{z}}$ For analysis of variance (ANOVA), SED $=$ standard error of the difference. For AT, data were $\operatorname{Ln}(x+1)$ transformed before the analysis but the nontransformed data are presented. Results were obtained after 6 days of incubation at $20^{\circ} \mathrm{C}$. 
D. vaccinii, a host-specific species, has been recognized as an aggressive pathogen that causes stem canker and dieback of Vaccinium spp. in other countries $(1,20)$. Although D. vaccinii was reported on blueberry plants in southern Chile in the late 1980s, in the present study, no isolates of Diaporthe were similar to $D$. vaccinii based on morphology and phylogenetic analysis. Maybe, the identification of $D$. vaccinii was a misidentification from the late 1980s when no molecular analyses was conducted (12). It currently appears to be restricted to the United States, Canada, and possibly Lithuania but may be absent in South American countries $(1,8)$.

Diaporthe spp. were isolated from blueberry stems of different commercial cultivars in a wide geographic zone that varied along a gradient, from north to south, from relatively dry to relatively humid conditions. Although Diaporthe spp. associated with fruit decay have rarely been observed in Chile, these isolates infect fruit under laboratory conditions, suggesting that Diaporthe spp. from blueberry are not tissue-specific, as reported for other species (25). It is possible that the inoculum availability and weather conditions may limit fruit infection under Chilean conditions.

In this study, D. australafricana was the species most frequently isolated from blueberry stems, followed by $D$. ambigua, $D$. neotheicola, and $D$. passiflorae. The pathogenicity assays showed that $D$. ambigua and D. australafricana were among the most virulent species on blueberry.

At present, D. australafricana has been found only in grapevines in Australia and South Africa $(32,33)$, and an early report of its presence in Chile was already published (15). Therefore, these results add a new host to D. australafricana, confirm its pathogenicity to grapevine, and suggest the lack of host specificity. However, D. australafricana has not been found attacking grapevines in Chile. It is of interest that variations in virulence were obtained among isolates of $D$. australafricana. The most virulent isolate on grapevine shoots was the least virulent isolate on shoots of blueberry, apple, and pear. Because only one host cultivar was used, further studies are needed to better understand the role of $D$. australafricana in stem canker of blueberry.

The isolates of Diaporthe spp. obtained from the Chilean blueberry exhibited different optimal temperatures for mycelial growth, suggesting the versatility and adaptability of these pathogens. With the exception of $D$. ambigua, the optimal temperature was between 20 and $25^{\circ} \mathrm{C}$ and the maximal temperature for mycelial growth was $30^{\circ} \mathrm{C}$. However, the optimum growth temperature for $D$. ambigua was between 25 and $30^{\circ} \mathrm{C}$, and remarkably, it grew at $35^{\circ} \mathrm{C}$. This could explain why D. ambigua was isolated only from blueberry plants established in relatively warm areas.

Temperature appeared to have a pronounced effect on perithecial formation in $D$. ambigua and $D$. australafricana because perithecia formed mainly at $10^{\circ} \mathrm{C}$ but did not form at $5^{\circ} \mathrm{C}$. As previously reported (33), D. ambigua and D. australafricana are homothallic. Regardless of the incubation temperature, D. neotheicola, D. passiflorae, and Diaporthe sp. 1 did not form perithecia on autoclaved stems of alfalfa and blueberry. Considering that these Diaporthe isolates were from hyphal tip cultures, it is possible that self-incompatibility, such as has been reported for D. neotheicola (23), explained the lack of perithecial formation on autoclaved stems of alfalfa and blueberry.

In conclusion, this study has shown significant information regarding the etiology of the stem canker, demonstrating that at least four species of Diaporthe are primary pathogens, capable of causing stem canker symptoms on blueberry. These species are host nonspecific and may act alone or together and, to our knowledge, these results add new records of Diaporthe spp. on blueberry in South America, including D. ambigua, D. neotheicola, and D. passiflorae. However, the present results do not exclude the possibility that other species of Diaporthe may eventually be involved in this syndrome of blueberry. More information on the biology and relative importance of these species of Diaporthe is needed, for a better understanding of the epidemiology of the stem canker, in order to implement sound control strategies.

\section{Acknowledgments}

This project was supported by FONDECYT project 1100246 . We thank A. France, INIA-Quilamapu Chile, for providing a reference isolate of D. neotheicola.

\section{Literature Cited}

1. Anonymous. 1997. Diaporthe vaccinii Shear. Pages 737-741 in: Quarantine Pests of Europe. CABI/EPPO, Wallingford, Paris.

2. Ash, G. J., Sakuanrungsirikul, S., Anschaw, E., Stodart, B. J., Crump, N., Hailstones, and Harper, J. D. I. 2010. Genetic diversity and phylogeny of a Phomopsis sp., a putative biocontrol agent for Carthamus lanatus. Mycologia 102:54-61.

3. Carbone, I., Anderson, J. B., and Kohn, L. M. 1999. A method for designing primer sets for the speciation studies in filamentous ascomycetes. Mycologia 91:553-556.

4. Coller, G. J., Denman, S., Groenewald, J. Z., Lamprecht, S. C., and Crous, P. W. 2005. Characterisation and pathogenicity of Cylindrocladiella spp. associated with root and cutting rot symptoms of grapevines in nurseries. Australas. Plant Pathol. 34:489-498.

5. Crous, P. W., Summerell, B. A., Shivas, R. G., Burgess, T. I., Decock, C. A., Dreyer, L. L., Granke, L. L., Guest, D. I., Hardy, G. E. St. J., Hausbeck, M K., Hüberli, D., Jung, T., Koukol, O., Lennox, C. L., Liew, E. C. Y., Lombard, L., McTaggart, A. R., Pryke, J. S., Roets, F., Saude, C., Shuttleworth, L. A., Stukely, M. J. C., Vánky, K., Webster, B. J., Windstam, S. T., and Groenewald, J. Z. 2012. Fungal Planet Description Sheets:107-127 Persoonia 28:138-182.

6. Espinoza, J. G., Briceño, E. X., Chávez, E. R., Úrbez-Torres, J. R., and Latorre, B. A. 2009. Neofusicoccum spp. associated with stem canker and dieback of blueberry in Chile. Plant Dis. 93:1187-1194.

7. Espinoza, J. G., Briceño, E. X., Keith, L. M., and Latorre, B. A. 2008. Canker and twig dieback of blueberry (Vaccinium spp.) caused by Pestalotiopsis spp. and Truncatella sp. in Chile. Plant Dis. 92:1407-1414.

8. Farr, D. F., Castlebury, L. A., and Rossman, A. Y. 2002. Morphological and molecular characterization of Phomopsis vaccinii and additional isolates of Phomopsis from blueberries and cranberries in the eastern United States. Mycologia 94:494-504

9. Farr, D. F., Castlebury, L. A., Rossman, A. Y., and Putnam, M. L. 2002. A new species of Phomopsis causing twig dieback of Vaccinium vitis-idaea (lingonberry). Mycol. Res. 106:745-752.

10. Filatov, D. A. 2002. ProSeq: a software for preparation and evolutionary analysis of DNA sequence data sets. Mol. Ecol. Notes 2:621-624.

11. González, P., Alaniz, S., Montelongo, M. J., Rauduviniche, L., Rebellato, J., Silvera-Pérez, E., and Mondino, P. 2012. First report of Pestalotiopsis clavispora causing dieback on blueberry in Uruguay. Plant Dis. 96:914-914.

12. Guerrero, C. J., and Godoy, A. 1989. Detection of Phomopsis vaccinii (Shear, Stevens and Bein) in high bush blueberry (Vaccinium corymbosum L.). Agric. Téc. (Chile) 49:220-223.

13. Hawksworth, D. L. 2011. Naming Aspergillus species: progress towards one name for each species. Med. Mycol. 49:70-76.

14. Larkin, M. A., Blackshields, G., Brown, N. P., Chenna, R., McGettigan, P. A., McWilliam, H., Valentin, F., Wallace, I. M., Wilm, A., Lopez, R. Thompson, J. D., Gibson, T. J., and Higgins, D. G. 2007. Clustal W and Clustal X version 2.0. Bioinformatics 23:2947-2948.

15. Latorre, B. A., Elfar, K., Espinoza, J. G., Torres, R., and Díaz, G. A. 2012. First report of Diaporthe australafricana associated with stem canker on blueberry in Chile. Plant Dis. 96:768.

16. Latorre, B. A., and Torres, R. 2011. Diaporthe/Phomopsis complex associated with stem cankers of blueberry in Chile. (Abstr.) Phytopathology 101:S99.

17. Milholland, R. D. 1972. Histopathology and pathogenicity of Botryosphaeria dothidea on blueberry stems. Phytopathology 62:654-660.

18. Milholland, R. D. 1974. Stem and root rot of blueberry caused by Calonectria crotalariae. Phytopathology 64:831-834.

19. Mostert L., Crous P. W., Kang C. J., and Phillips A. J. L. 2001. Species of Phomopsis and a Libbertella sp. occurring on grapevines with specific reference to South Africa: morphological, cultural, molecular and pathological characterisation. Mycologia 93:146-167.

20. Ramsdell, D. C. 1995. Phomopsis canker. Pages 14-15 in: Compendium of Blueberry and Cranberry Diseases. F. L. Caruso and D. C. Ramsdell, eds. American Phytopathological Society, St. Paul, MN.

21. Rehner, S. A., and Uecker, F. A. 1994. Nuclear ribosomal internal transcribed spacer phylogeny and host diversity in the coelomycete Phomopsis. Can. J. Bot. 72:1666-1674.

22. Santos J. M., Correia V. G., and Phillips A. J. L. 2010. Primers for matingtype diagnosis in Diaporthe and Phomopsis: their use in teleomorph induction in vitro and biological species definition. Fungal Biol. 114:255-270.

23. Santos, J. M., and Phillips, A. J. L. 2009. Resolving the complex of $\mathrm{Di}$ aporthe (Phomopsis) species occurring on Foeniculum vulgare in Portugal. Fungal Divers. 34:111-125. 
24. Santos, J. M., Vrandečić, K., Cosić, J., Duvnjak, T., and Phillips A. J. L. 2011. Resolving the Diaporthe species occurring on soybean in Croatia. Persoonia 27:9-19.

25. Schilder, A. M. C., Erincik, O., Castlebury, L., Rossman, A., and Ellis, M. A. 2005. Characterization of Phomopsis spp. infecting grapevines in the Great Lakes region of North America. Plant Dis. 89:755-762.

26. Shenoy, B. D., Jeewon, R., and Hyde, K. D. 2007. Impact of DNA sequence data on the taxonomy of anamorphic fungi. Fungal Divers. 26:1-54.

27. Stromeng, G. M., and Stensvand, A. 2011. Seasonal pattern in production of conidia of Godronia cassandrae f. sp. vaccinii in high bush blueberry in Norway. Eur. J. Hortic. Sci. 76:6-11.

28. Swofford, D. L. 2002. PAUP*: Phylogenetic Analysis Using Parsimony. (*and Other Methods), version 4.0b10. Sinauer Associates, Sunderland, MA.

29. Tamura, K., Peterson, D., Peterson, N., Stecher, G., Nei, M., and Kumar, S. 2011. MEGA5: Molecular evolutionary genetics analysis using maximum likelihood, evolutionary distance, and maximum parsimony methods. Mol. Biol. Evol. 28:2731-2739.

30. Thompson, S. M., Tan, Y. P., Young, A. J., Neate, S. M., Aitken, E. A. B., and Shivas, R. G. 2011. Stem cankers on sunflower (Helianthus annuus) in Australia reveal a complex of pathogenic Diaporthe (Phomopsis) species. Persoonia 27:80-89.
31. Udayanga, D. Liu, X., Crous, P. W., McKenzie, E. H. C., Chukeatirote, E., and Hyde, K. D. 2012. A multi-locus phylogenetic evaluation of Diaporthe (Phomopsis). Fungal Divers. 56:157-171.

32. Udayanga, D., Liu, X., McKenzie, E. H. C., Chukeatirote, E., Bahkali, A. H., and Hyde, K. D. 2011. The genus Phomopsis: biology, applications, species concepts and names of common phytopathogens. Fungal Divers. 50:189-225.

33. van Niekerk, J. M., Groenewald, J. Z., Farr, D. F., Fourie, P. H., Halleen, F., and Crous, P. W. 2005. Reassessment of Phomopsis species on grapevines. Australas. Plant Pathol. 34:27-39.

34. van Rensburg, J. C. J., Lamprecht, S. C., Groenewald, J. Z., Castlebury, L. A., and Crous, P. W. 2006. Characterisation of Phomopsis spp. associated with die-back of rooibos (Aspalathus linearis) in South Africa. Stud. Mycol. 55:65-74

35. White, T. J., Bruns, T., Lee, S., and Taylor, J. 1990. Amplification and direct sequencing of fungal ribosomal RNA genes for phylogenetics. Pages 315 322 in: PCR, A Guide to Methods and Applications. M. A. Innis, D. H. Gelfand, J. J. Snisky, and T. J. White, eds. Academic Press, San Diego, CA

36. Wright, A. F., and Harmon, P. F. 2010. Identification of species in the Botryosphaeriaceae family causing stem blight on southern highbush blueberry in Florida. Plant Dis. 94:966-971. 